\title{
道路交通センサスを用いた札幌市の都市構造の解析
}

\section{Analysis of Urban Structure in Sapporo City by Using the Road Traffic Census}

\author{
三木祐太郎 ${ }^{*} \cdot$ 木村 圭司 $^{* *} \cdot$ 本間 利久** \\ Yutaro MIKI*, Keiji KIMURA ${ }^{* *}$ and Toshihisa HONMA**
}

キーワード：道路センサス、札幌市、都市構造

Key words : the Road Traffic Census, Sapporo City, urban structure

\section{I . はじめに}

道路は，私たちの日常生活を支える重要な社 会資本であるが，車利用の増加に伴い，渋滞や交 通事故, 地球環境への影響などの問題を引き起こ している。このような問題の解決に向けて, 国土 交通省では, 関係省庁, 都道府県, 政令指定市, 道路関係公社などと連携し，道路の交通量や自動 車の使われ方などを全国規模で調査する「道路交 通センサス」(正式名称は「全国道路・街路交通 情勢調査」)を実施している。道路交通センサス は，道路に関する国勢調査ともいうべきもので, 全国の道路の交通量及び道路現況を調査し, 道 路交通の現状と問題点を把握し, 将来にわたる道 路の整備計画の策定・建設・維持修繕その他の管 理などについての基礎資料を得る目的で実施され ている。道路交通センサスの調査結果は, 全体の データを整理して過去の調査結果と比較するなど して, 調査の目的にあるように将来にわたる道路 の整備計画の策定・建設・維持修繥その他の管理 や都市計画に活用されるほか, 地域別車種別の自 動車交通需要は, 将来の交通需要推計を行う際の 基礎資料として利用される。その他, 近年行わ れているものとして, 渋滞 3 Dマップの作成によ り渋滞状況の把握に活用されるほか, NOx（窒素 酸化物) PSPM (浮遊粒子状物質)などの車種別排 出原単位や排出量の算定の基礎資料としても活
用されているが，まだ実験段階のものも多い。こ うした自動車交通を指標として都市空間構造を解 析した例として, 河端(2007)が挙げられる。河端 （2007）は自動車と公共交通のアクセシビリティ格 差から都市空間構造の自動車依存性の解析を行っ ている。

一方で, 札幌の都市空間構造の解析として, 山口(1976) は国政統計区に加えて独自の地域統計 を整備した札幌市の地域構造を把握するため, 社 会地域分析に基づく因子生態学の手法を導入し て，都市内部の地域分化の様相を，都心部をとり まく住宅地域の社会的特性を中心に分析した。そ の結果，第 1 成分は “Family Status”，第 2 成 分は “Social Status” と解釈して，4 個の住民の 社会階層による分類を行った。これによれば，札 幌市の都市化地域における社会地域の概念図式 は，バージェスの同心円モデルとホイトの扇形モ デルの折贵型であり，“Family Status”という 社会空間が設定した同心円パターンに，“Social Status”という社会空間が楔状に喰い込んで, 全体として最大の人口を有する社会地域 III (Low Status·Large Families) が都市化地域拡大の推進 力となる市民層を含有すると述べている。また, 橋本 (2004) は建物用途別の延床面積に着目し, $1980,1986,1991$ 年の都市計画基礎調査デー夕を用 いて独自の準三相因子分析法を施した結果，建物

\footnotetext{
*住友電工株式会社

*Sumitomo Electric Co. Ltd.

**北海道大学大学院情報科学研究科

** Graduate School of Information Science and Technology, Hokkaido University
} 
用途の分布の年次ごとの変化を明らかにした。こ の結果，中心部に店舗施設が，周辺部に住宅施設 が卓越し，土地を多機能かつ高密度に利用しよう とする傾向が進んでいて，かつ業務施設を含む専 業商業施設が中心部に集中する傾向を強めている ことから, 都心部の核心地域では機能集中に伴っ て建物用途の純化が進んでいると橋本は述べて いる。また，JRおよび地下鉄沿線について，敷 設年次の新しい路線のほうが駅周辺の建物用途の 変化が激しく，地下鉄東西線や東豊線で，商業や サービス行が駅付近で近年急速な集中を示してい ることにも触れている。

道路交通センサスで取得されたデー夕は，物流 や人の移動を示す総合的な指標であり，都市の構 造を明らかにするためには有効であると考える。 そこで，本研究では，道路交通をはじめとする人 の流れと札幌の都市構造の関係を, 道路交通セン サスの調査を用いて検討することを目的とする。

\section{II. 使用したデータと解析方法}

道路交通センサスは, 昭和 3 年度に道路改良 会が実施した「全国交通調査」に端を発し，昭 和55年度以降は総合的調査として概ね 5 年に 1 回 (昭和 55 年度, 60 年度, 平成 2 年度, 6 年度, 11 年度, 17 年度)の割合で実施している。道路交通 センサスでの調査内容は, 交通量・旅行速度な どの実測を行う「一般交通量調査」と, アンケー 卜調査等により地域間の自動車の動きを把握する 「自動車起終点調査」に大別される。調査は年間 を通し最も平均的な交通状況であるといわれる秋 に実施される。平成17年度調査では，北海道は平 成17年10月16日 (日)，19日(水)の 2 日間に調査が 行われた。本研究では, このうち一般交通量調査 のデータを用いている。一般交通量調査は, 高速 道路, 一般国道, 都道府県道, 一部の指定市の一 般市道を対象として, 道路の幅員構成や交差点・ バス停・歩道の整備状況を調査する「道路状況調 査」と, 自動車・二輪車・歩行者の交通量を観測 する「交通量調査」，自動車で実走して速度を測 定する「旅行速度調査」の 3 つの調査からなる。 このうち交通量調査と旅行速度調査については, 平日は全箇所を対象に 1 日ずつ調査を行う。

解析対象範囲地域は図 1 に示す札幌市内のう
ち, 平成17年度の道路交通センサスの一般交通量 調査が行われた地点である。なお，平成17年度は 209地点で観測が行われた。

本研究では，まず札幌市における道路交通セン サスのデータから, 都市構造を示している調査項 目を抽出し，それぞれの分布図を作成した。しか しながら，道路交通センサスのデー夕は，さまざ まな要因が複雑に絡み合った結果を示していると 考えられる。そこで, 都市構造の構成要素を明ら かにするために，本研究では主成分型因子分析を 用い, さらに軸の回転を行って, 個々の構成要素 を明らかにしていく。

本研究では, 道路交通センサスの各調査項目 の相関係数を考慮した結果, 札幌の都市構造を明 らかにするために，(1)24時間交通量，(2)大型車率 (24時間交通量のうち大型車が占める割合), (3)歩 行者交通量, (4)自転車交通量, (5)バス交通量, (6)昼夜率, (7)法定速度達成率 (混雑時平均旅行速 度 $\div$ 法定速度), 8 ピーク率 (24時間交通量のうち ピーク時間が占める割合), という $8 つ 0$ 調査結 果に絞って解析を行うことにした。

道路交通センサスの調査結果は平日・休日の 2 種類があるが, 本研究では通勤・通学などを考 慮に入れたいため, 平日の調査結果のみを用いる

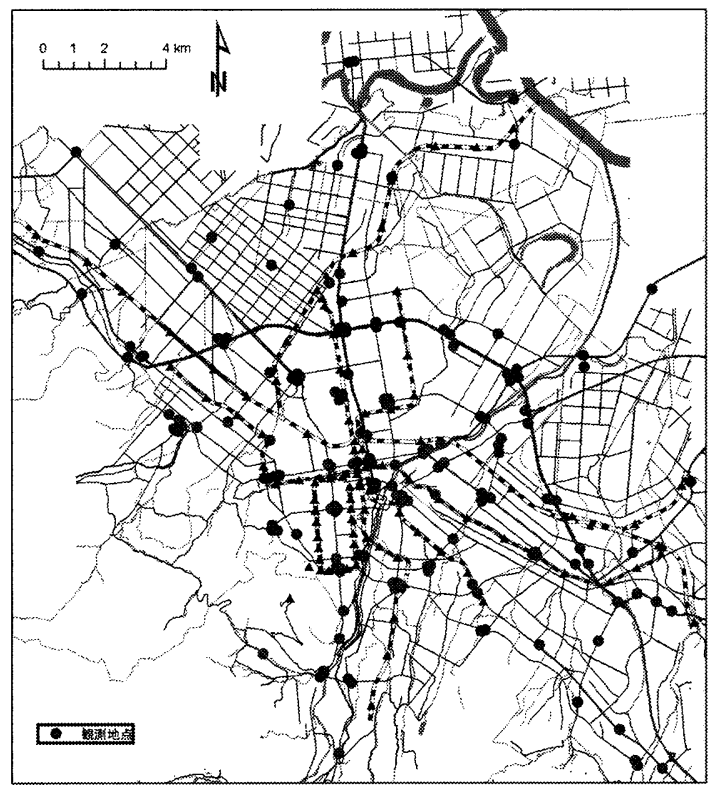

図 1 解析対象地域（交通センサス一般交通量調査 の観測地点） 
こととした。なお, 以上の項目のうち歩行者交通 量・自転車交通量・バス交通量についてはそのま まの数值を用いると, 地点ごとの值のばらつきが 大きすぎるため，それぞれの対数值を使用してい る。

\section{III. 札幌市における交通センサス指標を用いた札 幌市の地域概観}

24時間交通量は，図 2 で示されるように，まず 中心部の札幌駅付近で多く，次にそこから放射状 に広がる国道(特に36号線・230号線)で多くなっ ている。逆に，国道から離れている地域(地下鉄 東西線の西側など) は総じて自動車の交通量が少 ない。

大型車率 (24時間交通量のうち大型車が占める 割合)は, 自動車類交通量に対する大型車(バス, 普通貨物車) 交通量の割合を百分率で表したもの である。

$$
\text { 大型車率 }=\frac{\text { 大型車交通量 }}{\text { 全車交通量 }} \times 100
$$

大型車率は図 3 で示されるように，国道274号 線(札幌新道)や新川通など, バイパス的な役割を 果たしている道路で最も大きい。市中心部に向

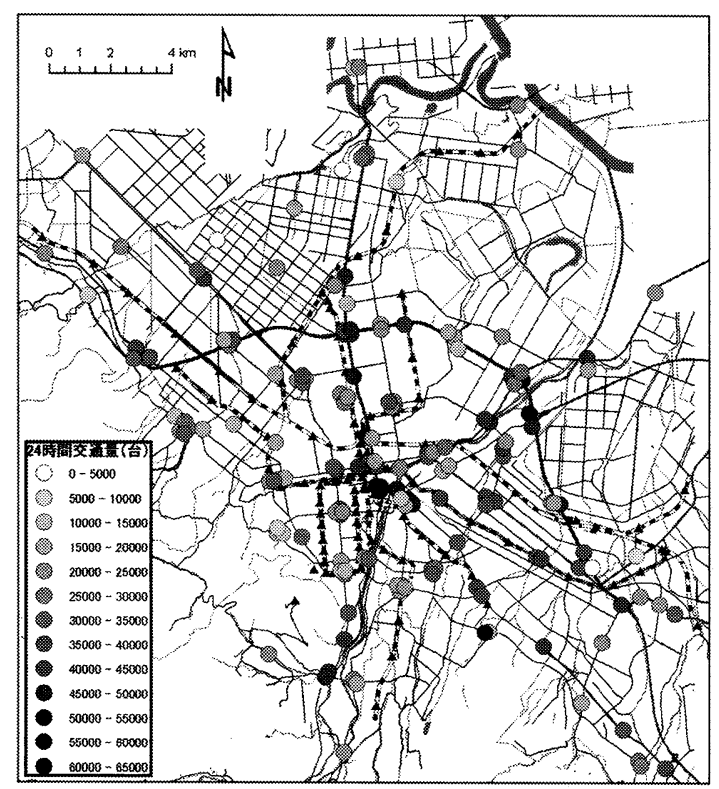

図 224 時間交通量の分布
かう道路よりも, 市周辺で割合が大きくなってい る。

歩行者交通量は図 4 で示されるように, 市中心 部で最も多い。また，地下鉄の駅周辺でも多く なっている。大型車率とは逆相関になっている。

自転車交通量は，図 5 で示されるように，歩行 者交通量とほほ同じ分布である。ただし, 歩行者 交通量よりも中心部から離れた地域(特に北区・ 東区) で比較的交通量が多い。

バス交通量は図 6 で示されるように，市中心 部や国道36号線・230号線・453号線で交通量が多 い。逆に同じ国道でも 12 号線や 5 号線ではそれほ ど多くない。これは，前者には並行する鉄道がな いので，そのぶん路線バスが多く走っているため だと考えられる。

昼夜率は図 7 で示されるように, 自動車類 24 時 間交通量の自動車類昼間12時間 ( 7 時〜19時)交通 量に対する割合であり，次の式で定義される。

$$
\text { 昼夜率 }=\frac{\text { 自動車類 } 24 \text { 時間交通量 }}{\text { 自動車類 } 12 \text { 時間交通量 }}
$$

昼夜率はほぼ同心円状に変化する構造をとって いることが図 7 よりわかる。昼夜率は24時間交通 量を 12 時間交通量で割った值なので，昼夜率が高

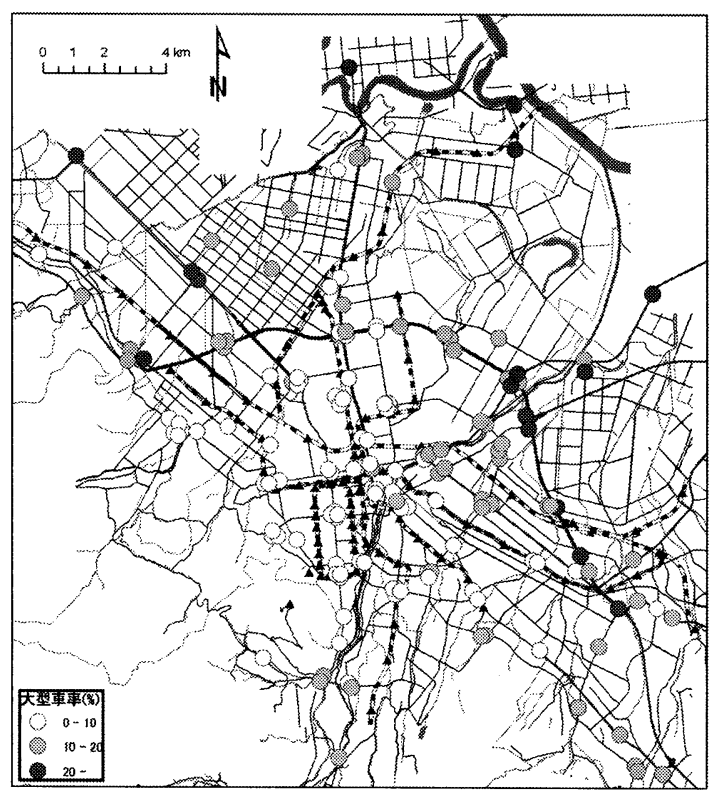

図 3 大型車率の分布 


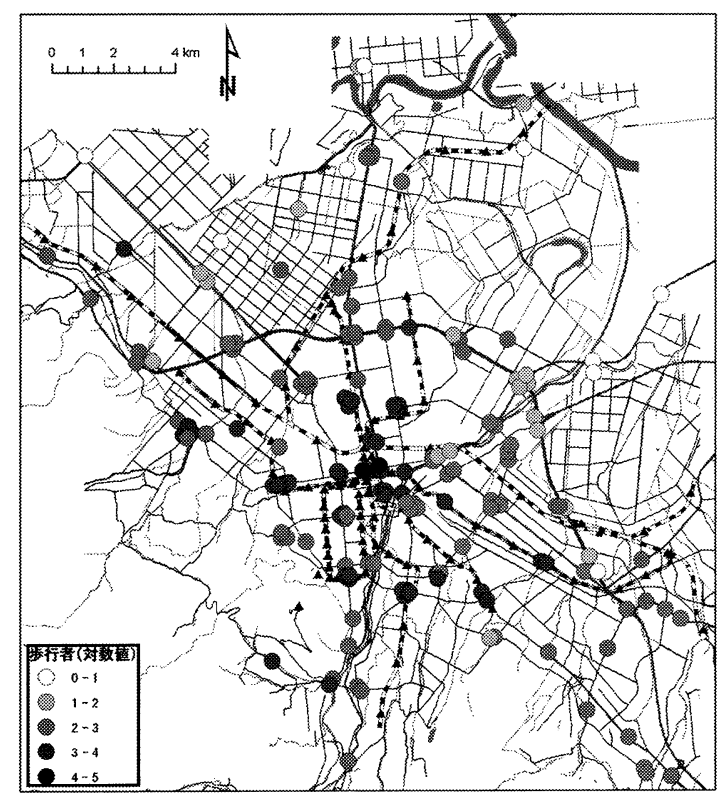

図4 歩行者交通量の分布（対数値）

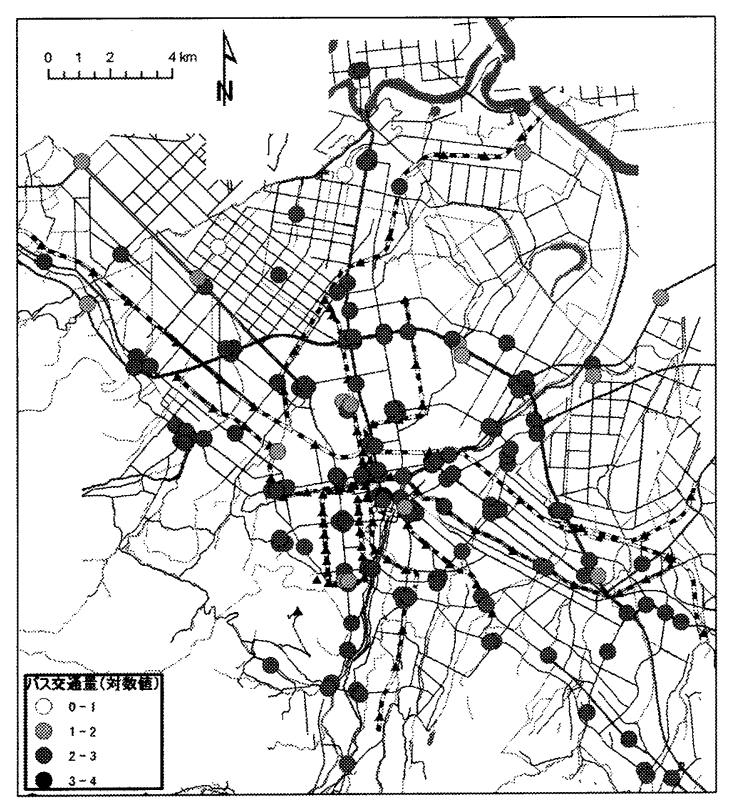

図 6 バス交通量の分布（対数值）

いということは夜間でも自動車の交通が多いと解 釈できる。逆に, 昼夜率が低いと自動車の交通は 昼間に集中している。郊外の住宅地ほどこの傾向 は顕著に現れている。ただし，他都市に向かう国 道では郊外でも昼夜率は他地点と比較して高い。

法定速度達成率 (混雑時平均旅行速度 $\div$ 法定速 度) は, 混雑度の指標として扱う。混雑時旅行速

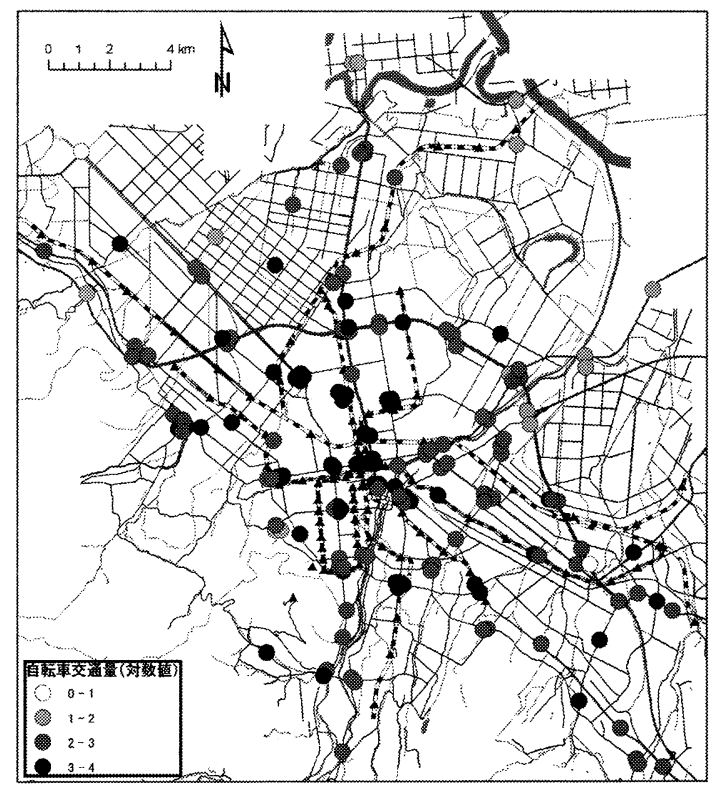

図 5 自転車交通量の分布（対数值）

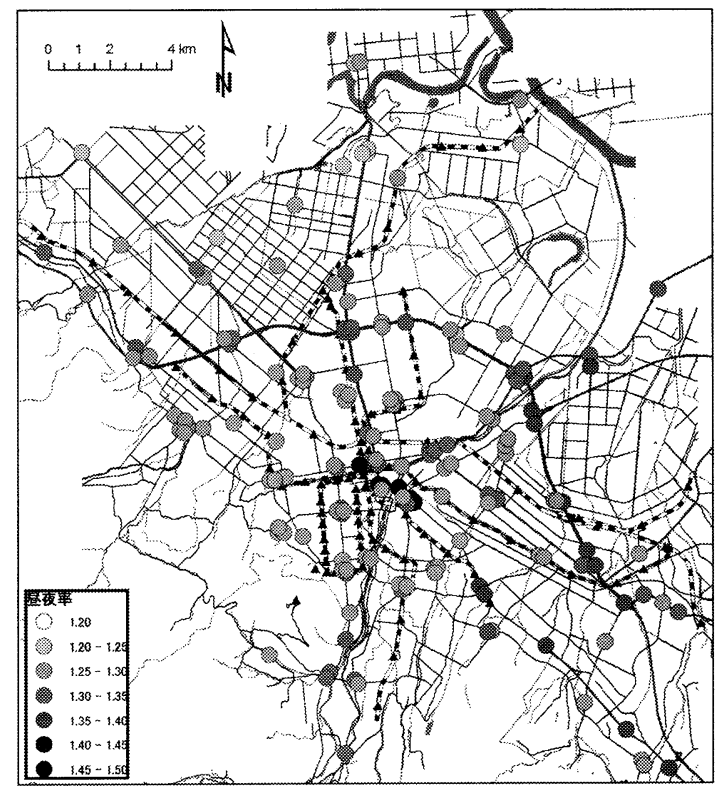

図 7 昼夜率の分布

度は, 調査区間の延長を信号や渋滞等による停止 時間を含めた調查区間の所要時間で除したもので ある。また, 法定速度は道路標識等により表示さ れている指定最高速度であるが, 最高速度が指定 されていない道路については, 道路交通法施行令 で定められた最高速度を使用した。なお，指定最 高速度が車種別に異なる場合については, 普通乗 
用車の值を用いた。観測された旅行速度をその道 路の法定速度で割った值なので，この值が低いほ ど，その道は「混雑している」といえる。図 8 を 見ると, 中心部では低く，逆に郊外では高くなっ ている。ただし，旅行速度は道路交通センサスで は混雑時のみの測定であるため, 次項のピーク時 間帯の占める割合と重ねて考える必要がある。

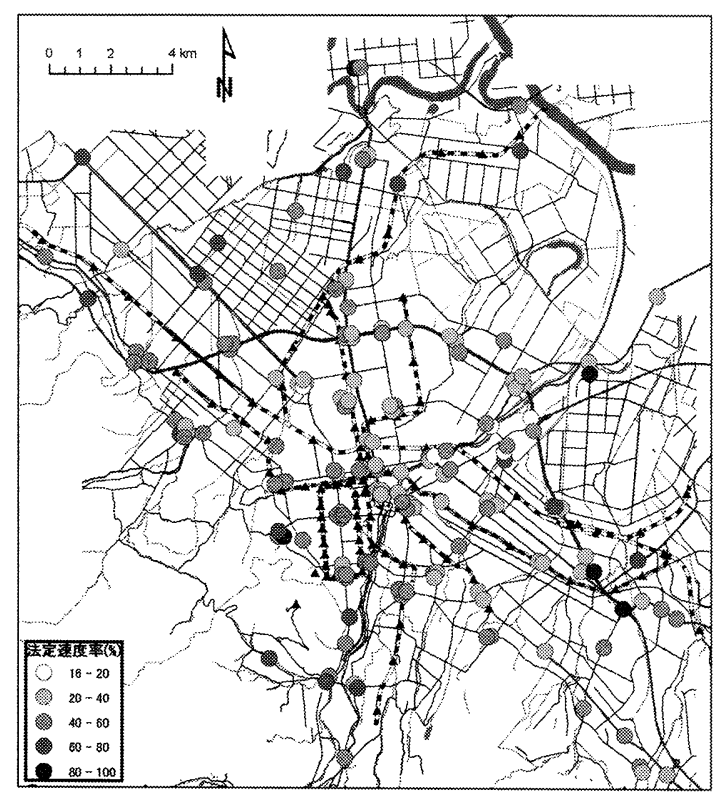

図 8 法定速度達成率の分布

ピーク率 (24時間交通量のうちピーク時間が占 める割合) は，通勤時間帯の混雑度の指標である と考えられる。ピーク時間交通量とは，上り下 り合計の交通量が最も多い時間帯 (1 時間)の自動 車類交通量であり，ピーク時間帯の占める割合が 高いということは，通勤時間帯に自動車の交通が 集中しているということである。図 9 を見ると, 中心部や郊外ではピーク率が高い。道路で考える と, 国道 5 号線や36号線が郊外でもピーク率が低 くなっている。これは, 小樽市や千歳市方面に往 来する自動車が通勤時間帯に限らず多いことを意 味していると考えられる。

\section{IV. 交通センサスによる札幌市の都市構造分析}

交通センサスデータから，札幌市の都市構造を 分析するには，特徴集約的な統計解析手法が必要 である。ここでは, 主成分型因子分析を行って,

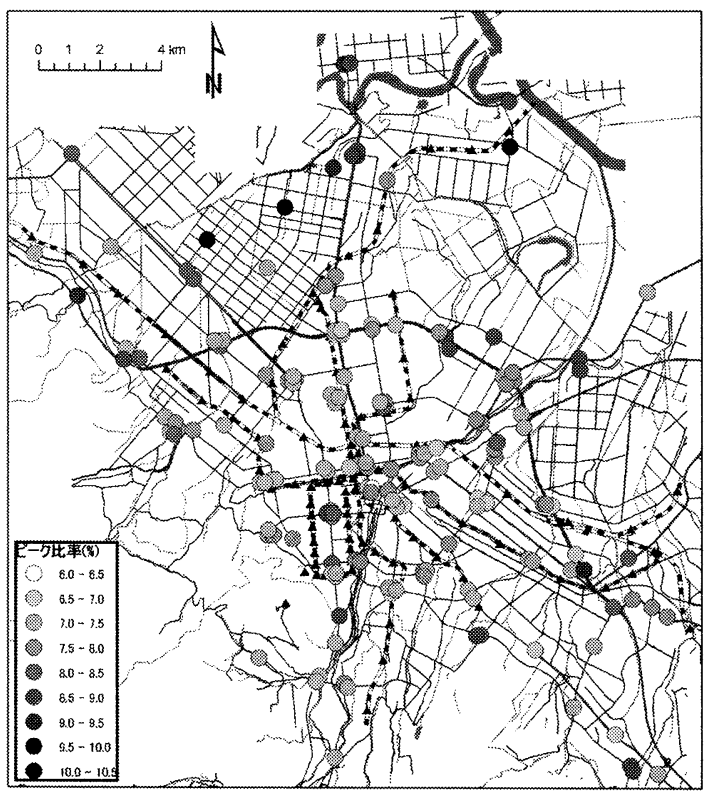

図 9 ピーク率の分布

特徵量を抽出した。なお，因子分析の行には地 点, 列にはセンサスの 8 項目とし, 行列要素には センサス值（一部の指標は対数を取って）相関行 列を用いた。

因子分析を行った結果，表 2 より抽出後の負 荷量平方和をみると，第 2 因子までが固有値 1 を 超え，第 2 因子までの累積寄与率が $64.7 \%$ となる が，第 2 因子と第 3 因子の因子寄与率がほぼ同じ であるため，この因子分析では第 3 因子までを採 択した。さらに，抽出された 3 つ因子軸に回転を かけ, 方向性の似た変数群の説明の助けとした。

表 1 因子分析の固有值と寄与率

\begin{tabular}{|c|c|c|c|}
\hline & 固有值 & 寄与率(\%) & 累積寄与率(\%) \\
\hline 第 1 因子 & 4.008 & 50.1 & 50.1 \\
\hline 第 2因子 & 1.169 & 14.6 & 64.7 \\
\hline 第 3 因子 & 0.980 & 12.2 & 77.0 \\
\hline 第 4 因子 & 0.688 & 8.6 & 85.6 \\
\hline 第 5 因子 & 0.398 & 5.0 & 90.5 \\
\hline 第6 因子 & 0.353 & 4.4 & 95.0 \\
\hline 第 7 因子 & 0.278 & 3.5 & 98.4 \\
\hline 第 8因子 & 0.126 & 1.6 & 100.0 \\
\hline
\end{tabular}




\section{1. 第 1 因子}

第 1 因子は表 1 より，寄与率は50.1\%である。 表 2 に示した各因子の項目ごとの重み付けをみる と, 第 1 因子の因子得点は, 歩行者・自転車・バ ス交通量，24時間交通量が正に高い因子負荷を付 与し, 逆に大型車率, ピーク率, 速度達成率が負 に高い因子負荷を付与した。また，昼夜率は負の 因子負荷であるが，この因子には大きな影響を与 えていない。これらから, 第 1 因子は「市街度」 と命名した。

市街度について, 解釈に関係しないと考えられ る因子得点の絶対值が 0.5 以内のものを地図上か ら除去した上で, 札幌駅を札幌市の中心として,

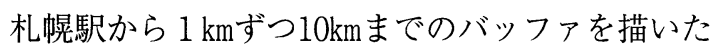
(図10)。図10から，正に高い成分得点を取る地域 が都心部に集中していることが分かる。さらに詳 細に分類を試みると, 中心から半径 $1 \mathrm{~km}$ 範囲は 札幌駅，大通など札幌市の行政や商業の中心地域 で，いわば札幌市のCBDといえる。この範囲で 除去されていない地点の因子得点は全て+ 1 以上 である。次に, 半径 $3 \mathrm{~km}$ 範囲をみると, おおよ そ環状通が囲む地域と一致する。そして, 半径 7 $\mathrm{km}$ の範囲をみると, 東西線の東側の数駅や南北線 の真駒内駅を除いて全ての地下鉄の駅がこの範囲

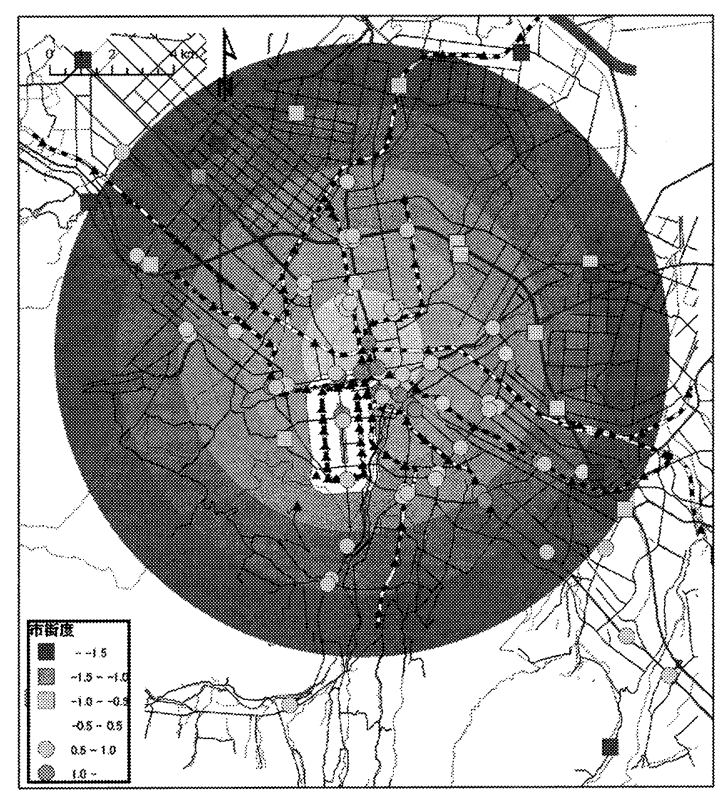

図10 第 1 因子（市街度）の因子負荷量分布と札幌駅 を中心とした同心円、地下鉄・市電の路線
内である。

なおこの範囲以外でも，国道230号線上の地点 や手稲駅近辺でも因子得点が高い地域があるが, 市街度に関しては, 都心からの距離によって分布 に特徴がみられると言える。

\section{2. 第 2 因子}

次に第 2 因子は，寄与率が $14.6 \%$ (累積寄与率 64.7\%)であり, 表 2 によると, 大型率の因子負 荷が第 1 因子で負に高く付与しているのに対し て, 第 2 因子では正に高く付与し, 歩行者と自 転車の成分負荷が第 1 因子と逆に正に付与してい る。24時間交通量やバスの交通量は付与の度合い は第 1 因子と大きく変化はない。また, 速度達成 率とピーク率については係数が小さく, 第 2 因子 にはほぼ影響していない。これらから，第 2 因子 は自動車による要因が大きく付与しているので 「バス・自動車通勤依存度」と命名した。

表 2 主成分型因子分析による軸回転後の因子行列 と各要素との相関

\begin{tabular}{|c|c|c|c|}
\hline (相関) & 第 1 因子 & 第 2 因子 & 第 3 因子 \\
\hline 24 時間交通量 & 0.618 & 0.647 & 0.261 \\
\hline 車率 & -0.682 & 0.494 & -0.093 \\
\hline 歩行者交通量 (対数) & 0.840 & -0.418 & 0.060 \\
\hline 自転車交通量（対数） & 0.859 & -0.290 & 0.009 \\
\hline バス交通量 (対数) & 0.680 & 0.399 & 0.376 \\
\hline 夜 & -0.383 & -0.235 & 0.784 \\
\hline 速 度 達 成 率 & -0.694 & -0.169 & 0.379 \\
\hline ピ $\quad$ - ク & -0.791 & -0.075 & -0.032 \\
\hline
\end{tabular}

第 2 因子の通勤自動車依存度については, 解 釈のために, 札幌市電から $500 \mathrm{~m}$ のバッファを, 地下鉄から $500 \mathrm{~m}$ と $1 \mathrm{~km}$ のバッファを描き, 第1因 子と同様に成分得点の絶対值が 0.5 以下の地点を 除去した(図11)。図11より, 負で高い因子得点を もっている地域は, 地下鉄から $1 \mathrm{~km}$ 以内の範囲の 地点がほとんどである。また，地下鉄から $1 \mathrm{~km}$ 内でなおかつ国道沿線でない地域はすべて負に高 い因子得点をとる。地下鉄沿線に居住している 人々は通勤においては自動車に依存していないと 考えられる。逆に国道230号線の南区の地域や国 道36号線，275号線は因子得点が正に高い地域が 
多く，負に高い地域はみられない。これは郊外か ら市中心部へ自動車で通勤する人々が多いことが 影響していると考えられる。

以上より，バス・自動車通勤依存度に関して は, 駅を中心とした小さな地域構造を示している といえる。

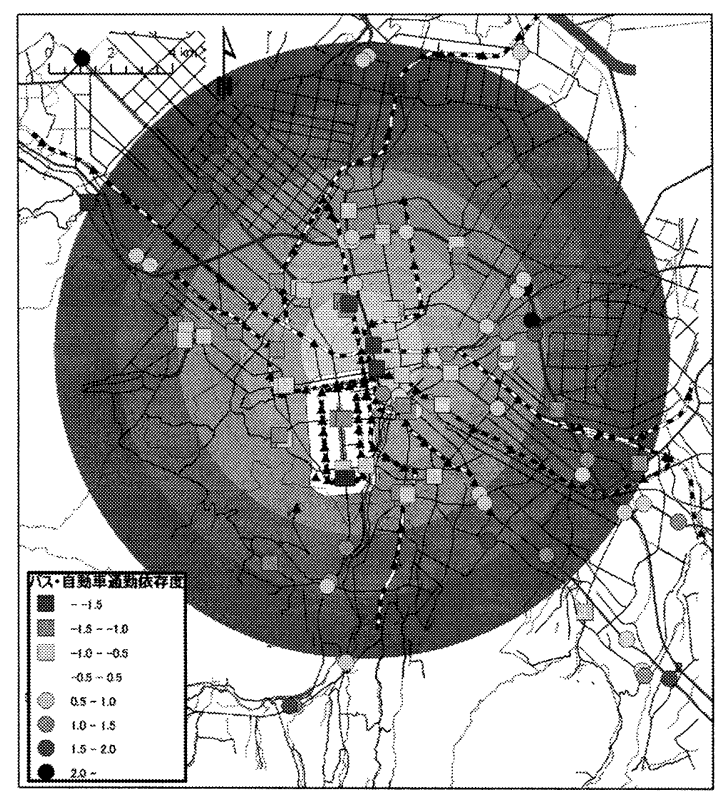

図11 第 2 因子 (バス・自動車通勤依存度)の因子負荷 量分布と札幌駅を中心とした同心円、地下鉄・ 市電の路線

\section{3. 第 3 因子}

最後に第 3 因子であるが，寄与率は $12.2 \%$ (累 積寄与率 $77.0 \%)$ であり, 昼夜率が他の項目に比 べ大きく因子負荷を付与している。他は速度達成 率, バス交通量, 24 時間交通量が正に因子負荷を 付与している。残る 4 項目は第 3 因子にほほ影響 していない。これらから, 第 3 因子は「道路の夜 間使用度」と命名した。

第 3 因子の道路の夜間使用度については，因子 行列から昼夜率が大きく因子得点に影響している ことがわかる。因子得点の絶対值が 0.5 以下の地

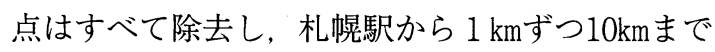
のバッファと地下鉄から $0.5 \mathrm{~km} \cdot 1 \mathrm{~km}$ のバッファ を描画した(図12)ところ, 国道230号線で因子得 点が正に高く, 札幌新道 (国道 5 号・274号線)で は負に高くなっている。それ以外ではJR函館本
線・千歳線で分けられる北側では負に高い因子得 点, 南側では正に高い因子得点をとる地点が多 い。

更なる解釈のために，国道から $250 \mathrm{~m}$ と $500 \mathrm{~m}$ の バッファを描いた(図13)ところ，札幌新道や国道

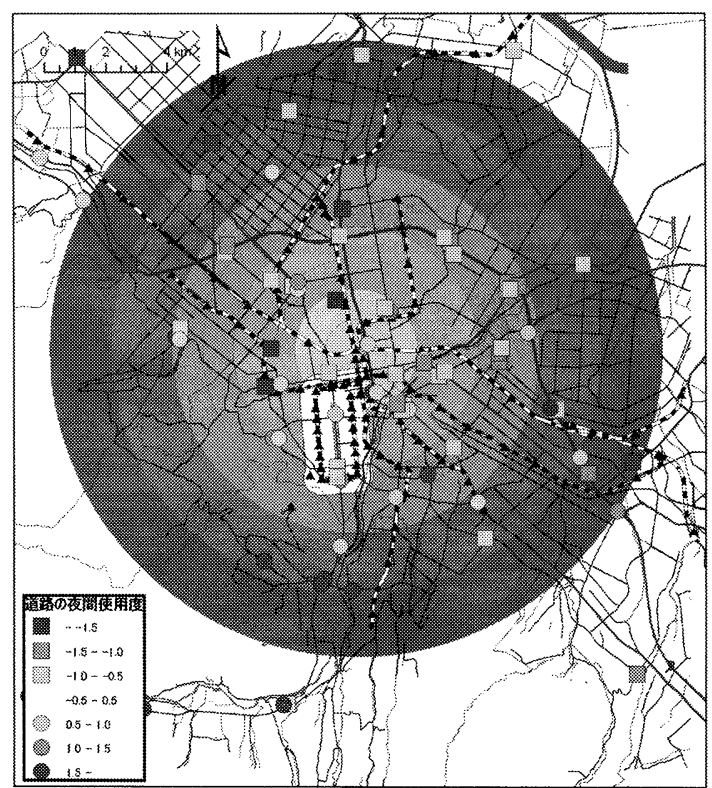

図12 第 3 因子（道路の夜間使用度）の因子負荷量分 布と札幌駅を中心とした同心円、地下鉄・市電 の路線

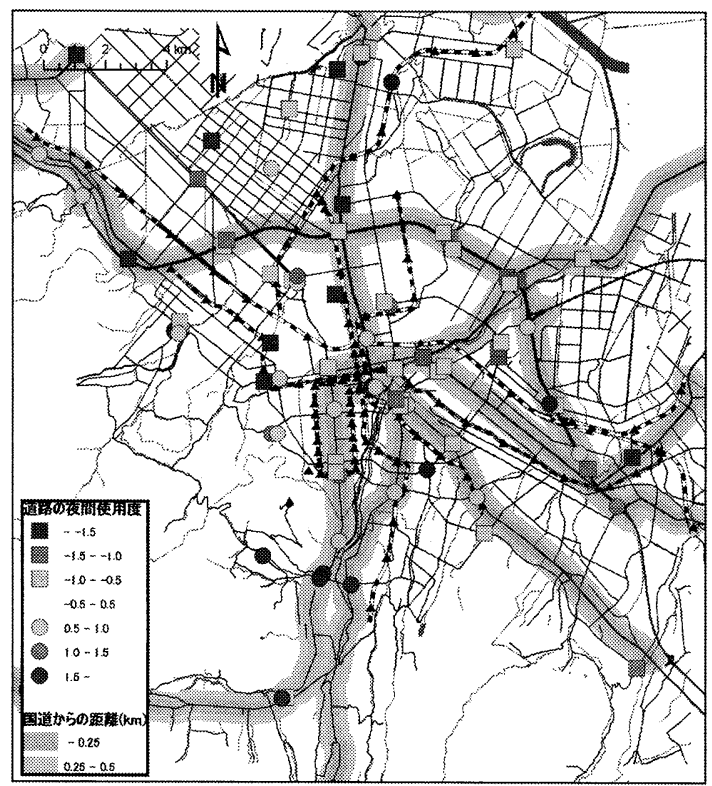

図13 第 3 因子（道路の夜間使用度）と一般国道 
275号線では因子得点が負に高い地点が多くを占 めていることが明らかになった。その理由として は，これらの路線は昼間ではバイパス的役割をし ているが，夜間は市街地を通る幹線も混雑してい ないため, 昼間に比べ夜間ではあまり利用されて いないためと考えられる。逆に，国道230号線で は正に高い因子得点となっているが，これは一本 道で抜け道がなく, 昼間も夜間も変わりなく利用 されていることが影響していると考えられる。

道路の夜間使用度に関しては，このように路線 ごとに特徴があり, 分布図はその違いを示してい るといえる。

\section{V. おわりに}

本手法は従来の都市構造の解析として, 道路交 通を主要因とする人の流れから都市の内部構造を 解析する点で今までにないものであり，意味のあ るものだと考える。

主成分型因子分析により抽出された各因子を 用いて分布図を作成したところ，道路交通から札 幌市の都市構造を解釈する一例を示すことができ た。実際の都市構造は, これらの因子が複合的に 重なって成立したものである。札幌市の都市構造 に関する先行研究と比較すると, 山口(1976)の結 果と近いものを示していると考えている。

また，道路交通センサスのデータは各都道府 県・政令指定都市により公開されており，全国ど の地域でも本研究と同様の手法にして解析が行え るほか, 過去の調査結果も豊富に残されているた め, 都市構造の時間的変化をみることも容易に可 能であると考える。この解析法は, 交通量調査の 観測地点が多い都市で有効であると考える。道路 交通センサスでは交通量が多い地域ほど観測地点 が多く設定されているので，地方中核都市などの 大都市では有効な手法であると考えられる。

さらに, 橋本 (2004)の研究では駅周辺について 詳述されているが, 本研究では，国道を主とした 幹線道路沿線地域の分布に特徴が表れている。

このように,これまで, 都市構造の解析には あまり使用されることがなかった交通センサス のデータを用いて, 札幌を例に都市構造の解析を 行った。今回は 1 時点だけのデータのみを用いた が, 中心部と郊外という大きな構造, 駅を中心と
する小エリアの地域性, 路線ごとの特徵といった 要素を抽出できた。特に, 路線ごとの特徵は, 交 通センサスならではの結果である。

今後, さらに進んだ解析を行うためには, 石狩 市, 江別市などを含んだより広域的な解析を行う ことが必要である。また，札幌市以外の地域，す なわち首都圈のような大都市圈や, 旭川市のよう な地方中核都市でも有効な手法かどうかを検討す る必要がある。一方で, 道路交通センサス調査に おいては, 都市の構造解析に適した観測地点の配 置を検討する必要があり, 札幌のような積雪の多 い都市では特に, 季節的な交通量の変化を考慮に 入れるため, 冬季積雪期間における交通量調査の 必要があろう。

\section{参考文献}

河端瑞貴 (2007)：アクセシビリティ格差からみた都市空間 構造の自動車依存性 日米の事例. 地理情報システム学 会講演論文集, 16, 439-442.

橋本雄一(2004)：建物用途からみた大都市内部の構造変容 一準三相因子分析法による札幌市の時空間分析一. 北海 道地理, 78, 23-50.

山口岳志 (1976)：札幌市の社会地域分析：因子生態学的研 究. 東京大学人文科學科紀要, 5, 83-103. 